\title{
Investigation of Mangrove Biomass Potential in Indragiri Hilir Wetlands, Indonesia
}

\author{
Ari Sandhyavitri, Fajar Restuhadi, Rudianda Sulaiman, Sigit Sutikno, and Koichi Yamamoto
}

\begin{abstract}
This study investigated the distribution of mangrove vegetation in the wetland area of Indragiri Hilir, Indonesia; and calculated the potential of the mangrove biomass through satellite image interpretation data, using Geographic Information System (GIS), combined with the field survey investigation (ground truth). It was identified that the mangrove area within this wetland was 118.747 ha with the biomass potential was approximately 41,648,651 ton. The majority of vegetation wereBakau (Rhizophoraapiculata) $38 \%$, Nyirih (Xylocarpusgranatum) 19\%, and Tumu (Bruguierasexangula) 13\%. The degradation of the mangrove area was approximately at the rate of $5,000 \mathrm{ha} /$ year $(2010-2013)$ Hence, there is a need to conserve mangrove vegetation as natural defenses/green belts in order to protect coastal area and to adapt to the climate change.
\end{abstract}

Index Terms-Mangrove, potential, biomass, Indonesia.

\section{INTRODUCTION}

The Geospatial Information Agency, Indonesia calculated that the mangrove forest area in Indonesia occupied3.2 million hectares (ha). This figure represented $19 \%$ of the entire mangrove ecosystem all over the world (data 2005) [1]. In the year 2013-2015, an extensive of land use changes in Indonesia has converted the mangrove forest areas to become palm oil plantation area, agriculture and costal development as well as public housings. This land conversion process has reduced the existing mangrove living in wetland areas significantly. However, Indonesia has been and is still considered as the largest mangrove ecosystem in the world [1]-[3].

The wetland areas in Indragiri Hilir are unique ecosystems covered by various types of mangrove vegetation. Indragiri Hilir is located at the Southern part of Riau Province, Indonesia at the position of $0^{\circ} 36^{\prime}$, North latitude, $1^{\circ} 07^{\prime}$, South latitude, $104^{\circ} 10^{\prime}$ East Longitude, and $102^{\circ} 32^{\prime}$ East Longitude. Indragiri Hilir covered of $11,605 \mathrm{~km}^{2}$ area, (Fig. 1 and 2).

The objectives of this study were to; identify the distribution of mangrove forest vegetation; and calculate the

Manuscript received February 18, 2016; revised April 7, 2016

Ari Sandhyavitri, Fajar Restuhadi, Rudianda Sulaeman, and Sigit Sutikno are with Universitas Riau, Pekanbaru 28293, Indonesia (e-mail: ari.sandhyavitri@gmail.com, rudianda1974@gmail.com, ssutiknoyk@ yahoo.com)

Koichi Yamamoto is with Yamaguchi University, Japan (e-mail: k_yama@yamaguchi-u.ac.jp). potential of mangrove biomass in Indragiri Hilir, Indonesia.

\section{CHARACTERISTICS OF MANGROVE Forest ECOSYSTEMS}

Commonly, the mangrove forests were easily found around the wetland and coastal areas of Indonesia especially in Sumatra, Kalimantan and Java Island [2].

The diversity of the mangrove species growing on this wetland ecosystem is influenced by various factors, including soil conditions, the rate of tides, salinity, levels of inundation, the deposition rates, erosion and water quality [4], [5]. The mangrove vegetation plays crucial roles in protecting wetland and coastal areas from abration. This vegetation also contains high carbon stocks which are considered to be a priority in climate change adaptation schemes, and mitigation strategies [6], [7]. Hence, preventing carbon emissions resulting from the destruction of mangrove ecosystems become crucial action plan [5], [8], [9].

\section{A. Methodology for Mapping}

This study analyzed data obtained from Land sat TM satellite image +7 using the vegetation index (NDVI) data.

The images processing of geological conditions, and soils classification are presented in Fig. 1. The images processing for land cover was presented in Fig. 2.

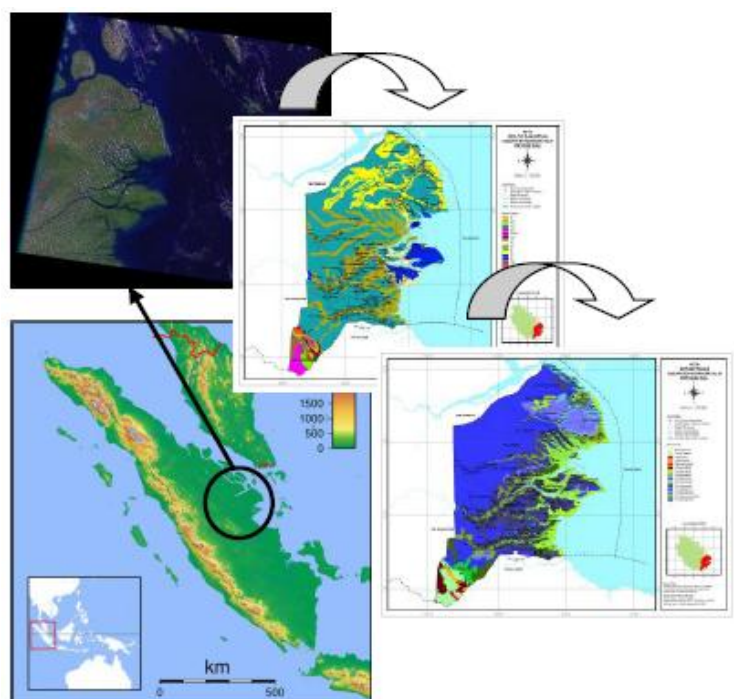

Fig. 1. Processing the satellite images for geological condition, and soils classification for Indragiri Hilir, Indonesia.

The reflection of each object on the satellite images has certain characteristics for each spectral waveform so that each object can be recognized for its differences.

The images obtained from the Land sat TM for Indragiri Hilir district contained two separate scenes. These both scenes need to be combined to yield a complete image of the research location. 


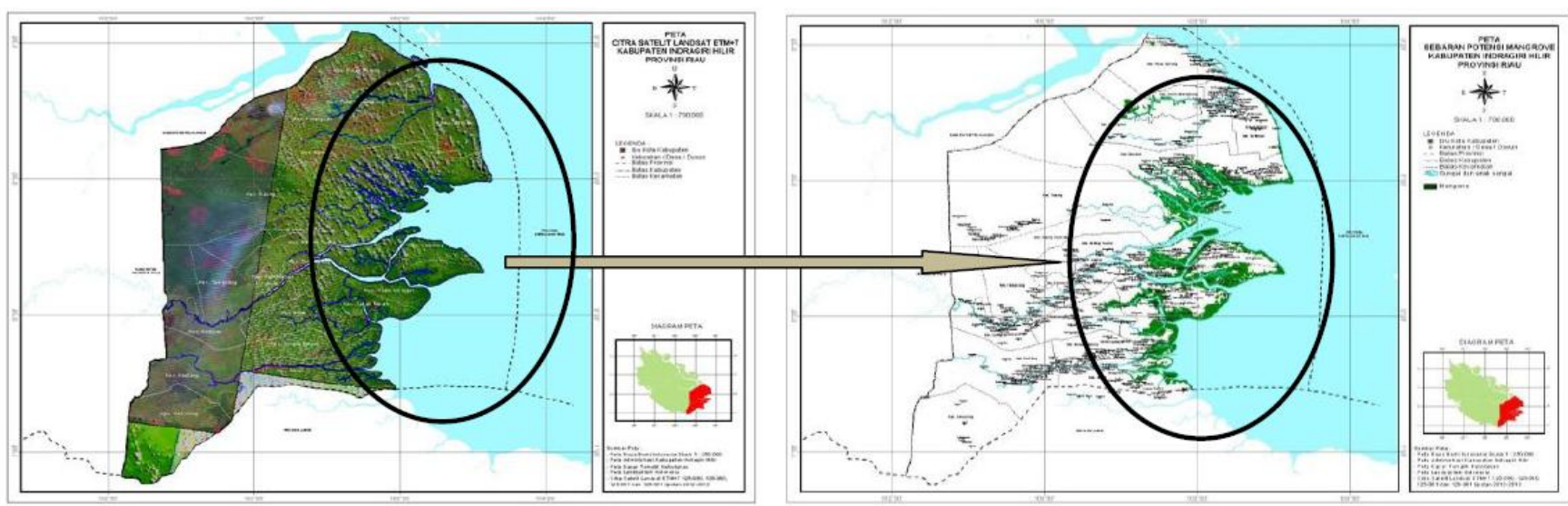

Fig. 2. Interpretation of satellite images for mangrove potential distribution map in Indragiri Hilir, Indonesia 2013.

The images error due to an atmosphere disturbances and distortions need to be eliminated for validating the images with the real situation in the field. This process consists of radiometric corrections and geometric corrections.

The histogram adjustment techniques were used to make satellite image corrections. These were used to eliminate the image distortions caused by the curvature of the earth, differences, and sensor elevation.

These geometric corrections were used some ground control points (GCP) based on the image reference data (year 2000). Each image coordinate was then transformed to a composite image with an acceptable rate of error (root mean error / RMS) of 0.01-0.99.

After obtaining the composite images, there was necessary to perform a supervised classification process with a maximum likelihood classification (MLC).

The results of this supervised classification process is a final image of Geographic Information System (GIS). This image was then verified with the ground truth (demplot) data. The final image (obtained from GIS and verified with the ground truth) would determine various land cover classes such as water body, forests, agriculture lands, and settlements.

\section{B. Measurement of the Mangrove Vegetation Biomass}

This study used a non - destructive technique for ground truth, in order to estimate the mangrove biomass per one hectare of area (Fig. 3). The results were then calculated using allometrict equation. Allometrict equation is made by finding the best correlation between the dimensions of the tree with its biomass [3], [5], [6], [10]. The result was then multiplied by a factor of 0.5 .

The model estimators for the mangrove tree biomass in Indonesia have been developed by several researchers [3], [4], [8]. For example the types of mangrove vegetation biomass (including Rhizophora spp., Bruguiera spp., and Avicennia spp) had been estimates by Kusmana, 1993 [8].

Tree biomasses:

$$
\begin{aligned}
& \text { Bruguiera spp. } \mathrm{W}=13.2359\left(\mathrm{e}^{1.31} \mathrm{D}-1\right) \\
& \text { Avicennia spp. } \mathrm{W}=0.2563\left(\mathrm{D}^{2} \mathrm{H}\right)^{0.8534} \\
& \text { Rhizopora spp. } \mathrm{W}=0.76 \mathrm{D}^{0.685}+2.901 \times 10^{-4}
\end{aligned}
$$

where:

$W=$ biomass $(\mathrm{kg})$
$D=$ tree diameter $(\mathrm{cm})$

$H=$ tree height (m)

\section{DETERMinAtion OF DEMPLOT SAMPLES}

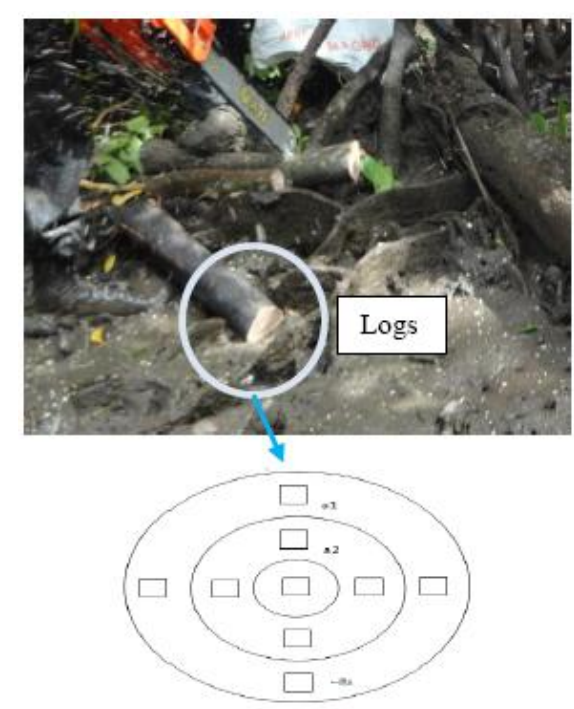

where:

Logs $=$ tree $\log s$

$a 1, a 2, \ldots, a n=$ dedicated samples

Fig. 3. Sampling test point of the tree biomasses.

An initial demplot sampling point was determined based on the distribution of the mangrove vegetation in Indragiri Hilir. It was obtained from the interpretation of Land sat satellite images. Then this image was cross-checked in the field (ground truth). The mangrove data species compositions and structures obtained from the site investigation (ground truth) are analyzed by the following formula [4], [9]-[12]:

$$
\text { Density }(h)=\frac{\text { Density }(h)}{\text { Demplot area }(h a)}
$$

Relative density $(K R)=\frac{\text { Density of a species }(h)}{\text { Density of all species }}$

$$
\text { Frequency }(F)=\frac{\text { Totalplotdiscovery of a species }(F)}{\text { The total number ofplots }}
$$

Relative Frequency $(F R)=\frac{\text { Frequency of a species }(F)}{\text { Frequency of all species }} \times 100 \%$

$$
\text { Dominance }(D)=\frac{\text { Basic spesies Area }}{\text { The Total plots area }} \times 100 \%
$$


Relative Dominance $(D R)=\frac{\text { Dominance of a species }(D)}{\text { Dominance of all species }} \times 100 \%$

Important IndexValue $(I N P)=K R+F R+D R$

\section{COLLECTING SAMPLES}

In order to obtain mangrove samples in the ground truth, there are 4 mangrove vegetation parts were collected including mangrove trees, trunks, branches and roots. These samples were cut into several segments. Each single segment for example mangrove tree was then made into $6 \mathrm{~cm}$ thick of slabs (logs), as shown in Fig. 3.

Each slab of the samples was then finally cut as many as six pieces of $2 \mathrm{~cm} \times 2 \mathrm{~cm} \times 2 \mathrm{~cm}$, as shown in Fig. 4 .

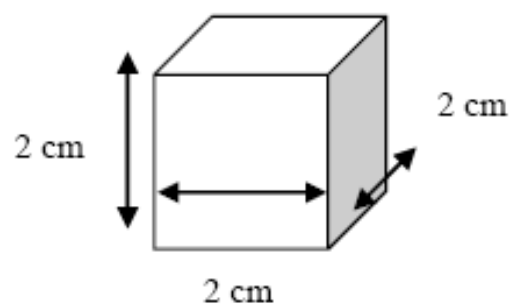

Fig. 4. An example of the sampling test of the tree trunk.

The dry biomass (dry weight) of the mangrove vegetation was calculated using the following equation:

$$
\begin{gathered}
\% K A=\frac{(B B c-B K c)}{B K c} \times 100 \% \\
B K=\frac{B B}{1+\left(\frac{\% K A}{100}\right)}
\end{gathered}
$$

where:

\% KA: Water content.

BK: Dry weight $(\mathrm{kg})$

BKc: Sample of dry weight (gram)

BB: Wet weight $(\mathrm{kg})$

BBc: Sample of wet weight (gram).

The total biomass of each mangrove vegetation was obtained from the calculation of the total trees+branches+ twigs+ leafs biomass [12].

\section{THE COMPOSITION OF THE MANGROVE SPECIES}

The composition of the mangrove species in Indragiri Hilir was obtained from the identification of the overall species encountered in sample plots presented in the sub-district area (kecamatan) based on the filed survey (ground truth). The plot samples were made as many as 225 demplots (Table I). These demplot areas are located in Mandah district (kecamatan), Tanah Merah and Kuala Indragiri. Each demplot was divided into several transection areas (Fig. 5).

TABLE I: DESCRIPTION OF THE NUMBER AND SAMPLING AREA

\begin{tabular}{|l|l|r|r|}
\hline No & Description & Demplot Number & Area (Ha) \\
\hline 1 & Big Tree & 225 & 2.2500 \\
\hline 2. & Small tree & 225 & 0.5625 \\
\hline 3. & Seedling & 225 & 0.0900 \\
\hline
\end{tabular}

Fig. 5 showed that a transection area at Mandah district demplot survey area (ground truth). This ground truth area was limited to the mangrove wetland areas close to shoreline and river banks in Indragiri Hilir. The number of demplot areas can be seen in Table I.

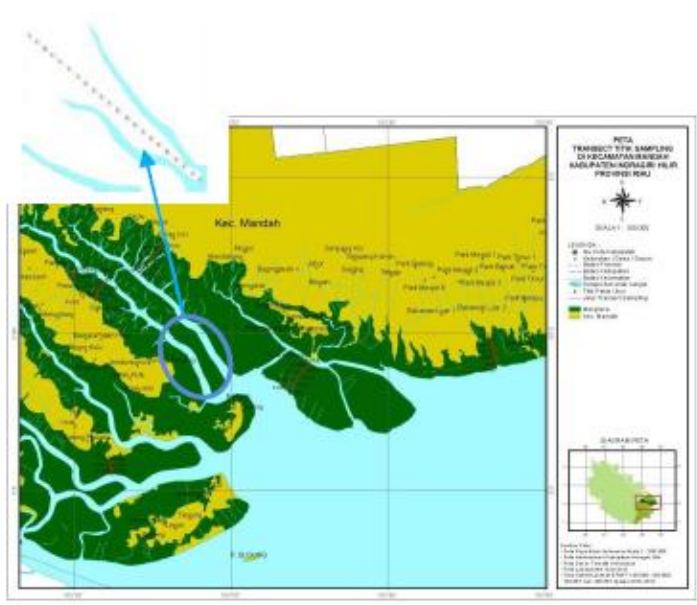

Fig. 5. Transection area at the demplot survey location.

The predominant mangrove vegetation identified in the filed areas encompassing 10species. These species are; i) Bakau (Rhizopora apiculata and Rh. mucronata), ii) Tumu (Bruguiera sexangula), iii) Nyirih (X. granatum), iv) Api-api (Avicennia marinaandAvicennia alba), v) Pedada ( $S$. AlbaandS. caseolaris), vi) Lankopit (Sonerata caeolaris), vii) Daek (Rhizophora mucronata), viii) Tongah (Ceriops tagal), ix) Perepat (Sonneratia alba), and x) Nypa (Nypa fruticans). This species then classified into eight groups as there were only small number (insignificant number) of Lankopit (Sonerata caeolaris) and Pedada (S. Alba and S. caseolaris) species found in the field area. Thus, these 2 species were not calculated in this paper.

\section{ESTIMATION OF MANGROVE TREES BIOMASS IN INDRAGIRI HILIR}

The total mangrove biomass per vegetation was presented in Fig. 6.

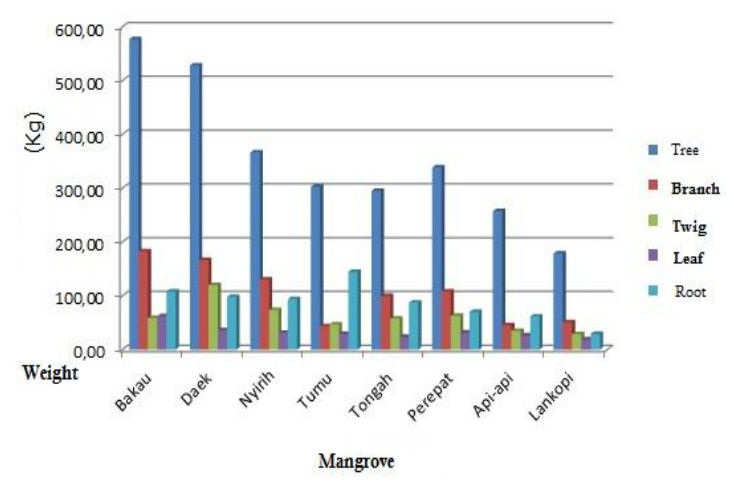

Fig. 6. Weight of the mangrove vegetation biomass in the field.

The calculation of the mangrove tree biomass ( $t / h a)$ from 225 demplots area $(10 \mathrm{~m} \times 10 \mathrm{~m})$ was determined based on a multiplication of the mangrove density with an average of the mangrove biomass (individual/ha) (Table II).

The dry weight of mangrove biomass can be obtained from the calculation of the wet vegetation biomass (757.75 ton/ha) minus its moisture contents.

Then it was identified that, the average of its dry weight (biomass) was 377.50 ton/ha (Table III). This biomass is 
relatively higher than the average of Acacia mangium biomass ages about 7 years (135 ton/ha) [13].

TABLE II: AN AVERAGE OF MANGROVE BIOMASS (TON / HA)

\begin{tabular}{|l|l|r|r|r|}
\hline No & Types & \multicolumn{1}{c|}{$\begin{array}{c}\text { Density } \\
\text { (individual/ha) }\end{array}$} & $\begin{array}{c}\text { Biomass } \\
\text { kg/tree }\end{array}$ & $\begin{array}{c}\text { Biomass } \\
\text { tree } \\
\text { (ton/ha) }\end{array}$ \\
\hline 1. & Bakau & 292.89 & 989.64 & 289.85 \\
\hline 2. & Daek & 17.33 & 949.37 & 16.46 \\
\hline 3. & Nyirih & 471.56 & 696.48 & 328.43 \\
\hline 4. & Tumu & 172.00 & 568.44 & 97.77 \\
\hline 5. & Tongah & 8.44 & 564.58 & 4.77 \\
\hline 6. & Perepat & 1.33 & 612.52 & 0.82 \\
\hline 7. & Api-api & 45.78 & 426.38 & 19.52 \\
\hline 8. & Nypa & \multicolumn{4}{|c}{ NA } & NA & NA \\
\hline & \multicolumn{4}{|c}{ Total } \\
\hline
\end{tabular}

Notes: Nypa (Nypafruticans) biomass was not calculated in this study because of this vegetation is classified as palm species, which is considered to be calculated separately.

TABLE III: AN AVERAGE of BIOMASS OF THE DRY MANGROVE TREES (TON / HA)

\begin{tabular}{|c|l|r|r|r|}
\hline No & Types & $\begin{array}{l}\text { Biomass } \\
\text { Tree } \\
\text { (ton/ha) }\end{array}$ & $\begin{array}{l}\text { Moisture } \\
\text { content } \\
\text { (KA) } \%\end{array}$ & $\begin{array}{l}\text { Dry weight } \\
\text { (ton/ha) }\end{array}$ \\
\hline 1. & Bakau & 289.85 & 100.94 & 144.25 \\
\hline 2. & Daek & 16.46 & 91.50 & 16.59 \\
\hline 3. & Nyirih & 328.43 & 101.99 & 50.53 \\
\hline 4. & Tumu & 97.77 & 93.49 & 2.33 \\
\hline 5. & Tongah & 4.77 & 104.52 & 0.41 \\
\hline 6. & Perepat & 0.82 & 98.56 & 8.79 \\
\hline 7. & Api-api & 19.52 & 122.18 & $\mathrm{NA}$ \\
\hline 8. & Nypa & NA & NA & 377.50 \\
\hline
\end{tabular}

\section{Distribution OF THE MANGROVE VEGETATION IN INDRAGIRI HILIR}

The frequency value $(\mathrm{F})$, relative frequency $(\mathrm{FR})$, density $(\mathrm{K})$, relative density (KR), and species dominance (D) of the mangrove vegetation (living on the entire plot surveyed areas) were used to identify the distribution of the mangrove vegetation in Indragiri Hilir.

The Nyirihtrees (Xylocarpusgranatum) had covered 51,103 ha, Bakau (Rhizophoraapiculata) covered 31,745 ha and Tumu (Bruguiera sexangula) was 18,636 ha. These three types of vegetation were identified as the largest mangrove species populations living in Indragiri Hilir (Table IV).

Based on the previous research study in Indragiri Hilir there was identified 2 Rhizophora vegetation types, such as mangroves (Rhizophora apiculata) and Daek (Rhizophora mucronata) with consist of 4 species [4]. The research study reported by Mimi Suarti, 2011 identified the mangrove forest areas in Indragiri Hulirwas 133.972 ha in 2010 [14].

Based on this study it was identified that the total mangrove area in Indragiri Hilirin 2013 was estimated to remain 118.747 hectares (Table IV).

The reduction of this mangrove forest area in2010 to 2013 was about 15 thousand hectares (133.972 ha- 118.747 ha).This was due to a contious deforestation process.

The deforestation rate was estimated at 5 thousand hectares per year.

Fig. 7 describes the potential area (ha) of various mangrove species per districts (kecamatan) in Indragiri Hilir at the tree level.

TABLE IV: Distribution of THE MANGRove AREAS(HA) IN INDRAGIRI HILIR BASEd ON District (KECAMATAN) ZONES

\begin{tabular}{|c|c|c|c|c|c|c|c|c|c|c|}
\hline No & District/Kecamatan & Bakau & Daek & Nyirih & Tumu & Tongah & Perepat & Api-api & Nypa & Total \\
\hline 1 & Kec. Concong & 2,198 & 130 & 3,539 & 1,291 & 64 & 10 & 343 & 476 & 8,054 \\
\hline 2 & Kec. Enok & 415 & 25 & 668 & 244 & 12 & 2 & 65 & 298 & 1,729 \\
\hline 3 & Kec. Gaung & 613 & 36 & 987 & 360 & 18 & 3 & 96 & & 2,114 \\
\hline 4 & Kec. Gaung Anak Serka & 1,603 & 95 & 2,581 & 941 & 46 & 7 & 250 & 100 & 5,627 \\
\hline 5 & Kec. Kateman & 380 & 23 & 611 & 223 & 11 & 2 & 59 & & 1.309 \\
\hline 6 & Kec. Kuala Indragiri & 8,423 & 499 & 13,560 & 4,945 & 244 & 38 & 1,315 & 3,207 & 32,244 \\
\hline 7 & Kec. Mandah & 9,104 & 540 & 14,656 & 5,344 & 264 & 41 & 1,422 & & 31,380 \\
\hline 8 & Kec. Pelangiran & 137 & 8 & 220 & 80 & 4 & 1 & 21 & $107^{2}$ & $5 / 8$ \\
\hline 9 & Kec. Pulau Burung & 160 & 9 & 257 & 94 & 5 & 1 & 25 & - & 551 \\
\hline 10 & Kec. Reteh & 1,800 & 107 & 2,897 & 1,057 & 52 & 8 & 281 & 1,382 & 7,586 \\
\hline 11 & Kec. Sungai Batang & 1,637 & 97 & 2,636 & 961 & 47 & 7 & 256 & 481 & 6.125 \\
\hline 12 & Kec. Tanah Merah & 4,305 & 255 & 6,930 & 2,527 & 125 & 19 & 672 & 2,415 & 17,254 \\
\hline 13 & Kec. Teluk Belengkong & 969 & 57 & 1,560 & 569 & 28 & 4 & 151 & 847 & 4,188 \\
\hline \multirow[t]{2}{*}{14} & Kec. Tembilahan & NA & NA & NA & NA & NA & NA & NA & 9 & 9 \\
\hline & TOTAL & 31,745 & 1,882 & 51,103 & 18,636 & 919 & 142 & 4,957 & 9,322 & 118,747 \\
\hline
\end{tabular}

TABLE V: DistRIBUTION OF THE MANGROVE BIOMASS IN INDRAGIRI HILIR BASED ON DiSTRICT (KECAMATAN) ZONES

\begin{tabular}{|c|c|c|c|c|c|c|c|c|c|c|}
\hline No & District/Kecamatan & Bakau & Daek & Nyirih & Tumu & Tongah & Perepat & Api-api & Nypa & Total \\
\hline 1 & Kec. Concong & $1,104,436$ & 65,137 & $1,236,600$ & 385,645 & 17,658 & 3,108 & 66,667 & 3,628 & $2,882,878$ \\
\hline 2 & Kec. Enok & 208,560 & 12,300 & 233,518 & 72,825 & 3,334 & 587 & 12,589 & 2,274 & 545,989 \\
\hline 3 & Kec. Gaung & 308,092 & 18,170 & 344,960 & 107,579 & 4,926 & 867 & 18,597 & & 803,191 \\
\hline 4 & Kec. Gaung Anak Serka & 805,508 & 47,507 & 901,901 & 281,266 & 12,879 & 2,267 & 48,623 & 762 & $2,100,712$ \\
\hline 5 & Kec. Kateman & 190,819 & 11,254 & 213,654 & 66,630 & 3,051 & 537 & 11,518 & & 497.463 \\
\hline 6 & Kec. Kuala Indragiri & $4,231,843$ & 249,583 & $4,738,256$ & $1,477,669$ & 67,659 & 11,907 & 255,445 & 24,451 & $11,056,813$ \\
\hline 7 & Kec. Mandah & $4,573,828$ & 269,752 & $5,121,166$ & $1,597,084$ & 73,127 & 12,870 & 276,088 & & $11,923,915$ \\
\hline 8 & Kec. Pelangiran & 68,650 & 4,049 & 76,865 & 23,971 & 1,098 & 193 & 4,144 & 816 & 179,185 \\
\hline 9 & Kec. Pulau Burung & 80,360 & 4,739 & 89,977 & 28,060 & 1,285 & 226 & 4,851 & - & 209,498 \\
\hline 10 & Kec. Reteh & 904,210 & 53,328 & $1,012,415$ & 315,731 & 14,457 & 2,544 & 54,581 & 10,532 & $2,367,798$ \\
\hline 11 & Kec. Sungai Batang & 822,569 & 48,513 & 921,004 & 287,224 & 13,151 & 2,315 & 49,652 & 3,669 & 2.148 .097 \\
\hline 12 & Kec. Tanah Merah & $2,162,741$ & 127,553 & $2,421,550$ & 755,183 & 34,578 & 6,085 & 130,549 & 18,408 & $5,656,647$ \\
\hline 13 & Kec. Teluk Belengkong & 486,922 & 28,717 & 545,190 & 170,023 & 7,785 & 1,370 & 29,392 & 6,459 & $1,275,858$ \\
\hline 14 & Kec. Tembilahan & $\mathrm{NA}$ & NA & $\mathrm{NA}$ & $\mathrm{NA}$ & NA & NA & NA & 9 & 9 \\
\hline & TOTAL & $15,948,538$ & 940,603 & $7,857,056$ & $5,568,890$ & 254,987 & 44,875 & 962,696 & 71,007 & $41,648,651$ \\
\hline
\end{tabular}

Table IV and Fig. 7 show the distribution of mangrove area

(ha) in 14 districts (kecamatan) in Indragiri Hilir. The District 
of Kuala Indragiri, Mandah, and Tanah Merah were considered as the most mangrove potential area encompassing Kuala Indragiri 32,244 ha, Mandah 31,380 ha, and Tanah Merah 17,254 ha.

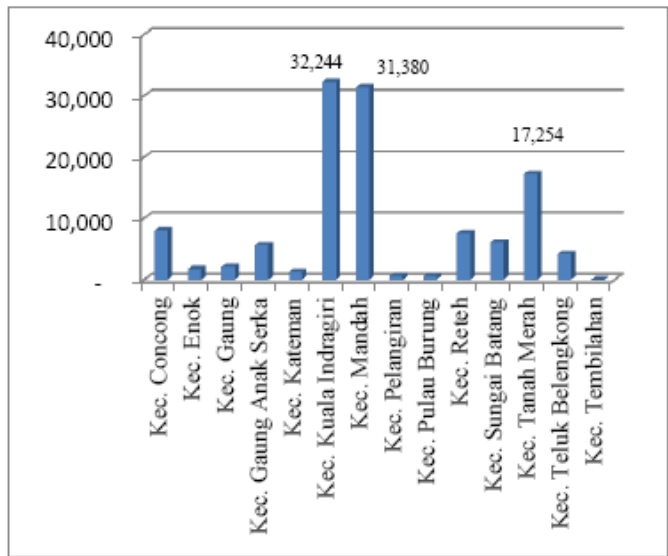

Fig. 7. Graph of the potential area (in ha) of various mangrove species in each district in Indragiri Hilir.

Table V and Fig. 8 show the distribution of the mangrove biomass (ton) in 14 districts (kecamatan) in Indragiri Hilir. The District of Kuala Indragiri consists of $11,056,813$ ton, Mandah 11,923,915 ton, and Tanah Merah 5,656,647 ton. Total mangrove biomass was estimated to $41,648,651$ ton.

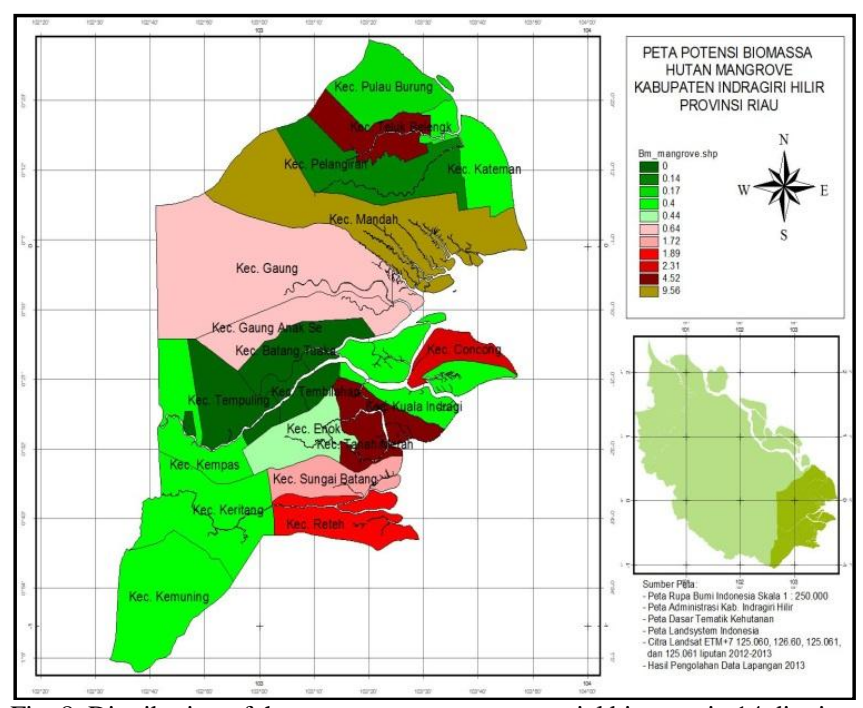

Fig. 8. Distribution of the average mangrove potential biomass in 14 districts (kecamatan) in Indragiri Hilir.

There were identified that the Bakau (Rhizoporaapiculata, Nyirih (X. granatum) and Rh. Mucronata), and Tumu (Bruguiera sexangula) were considered as the largest mangrove vegetation biomass potential with the following order; $15,948,538$ ton $(38 \%), 7,857,056$ ton $(19 \%)$, and $5,568,890$ (13\%) respectively (Table V).

This massive mangrove area in Indragiri Hilir was in need to be conserved in order to sustain the world mangrove ecosystems.

\section{CONCLUSION}

This paper identified that the total mangrove vegetation potential area in wetland of Indragiri Hilir. Indonesia was approximately 118.747 ha. The mangrove vegetation biomass potential was estimated to $41,648,651$ ton. Three main mangrove vegetation locations were identified as the following order Kuala Indragiri, Mandah, and Tanah Merah. These three locations are suggested to be conserved in order to mitigate the global climate change, and to protect wetland areas as well as coastal line within Indragiri Hilir, Indonesia.

\section{ACKNOWLEDGMENT}

Thanks are due to Research and Development Board (Balitbang) province of Riau. Riau University and all University colleagues' support in investigation of mangrove vegetation in Indragiri Hilir. and in the development of this paper.

\section{REFERENCES}

[1] W. C. Adinugroho, I. Syahbani, M. T. Rengku, Z. Arifin, and D. Mukhaidil, Balai Penelitian Kehutanan Samboja, Manuskrip, 2006, pp. 3-10.

[2] D. M. Alongi, "Present state and future of the world's mangrove forests," Environmental Conservation, vol. 29, 2002, pp. 331-349.

[3] Wetlands International. Peta Luasan Sebaran Gambutdan Kandungan Karbon di Sumatera Year 1990-2002, p. iii.

[4] E. Hilmi, Disertasi. Program Pascasarjan Institut Pertanian Bogor, Indonesia, 2003.

[5] P. Hutchings and P. Saenger, Ecology of Mangrove, University of Queensland Press, New York, 1987, pp. 10-33.

[6] S. Brown, Estimating Biomass and Biomass Change of Tropical Forest, USA: FAO, 1997

[7] S. Brown, J. Sathaye, M. Cane1, and P. Kauppi, "Mitigation of carbon emission to the atmosphere by forest management," Commonwealth Forestry Review, 1996, vol. 75, pp. 80-91.

[8] C. Kusmana. A Study on Mangrove Forest Management Based on Ecological Data in East Sumatra. Indonesia, Dissertation, Japan: Kyoto University, 1993, pp. 19-37.

[9] J. Bochove, E. Sullivan, and T. Nakamura, The Importance of Mangroves to People: A Call to Action, UNEP World Conservation Monitoring Centre (UNEP-WCMC), United Nations Environment Programme 2014, World Conservation Monitoring Centre (UNEP-WCMC).

[10] J. E. Ong, W. K. Gong, and C. H. Wong, "Allometry and partitioning of the mangrove rhizophoraapiculata," Forest Ecology and Management, vol. 188, issue 1-3, pp. 359-408, 2004.

[11] Onrizal, Taman Nasional Danau Sentarum Kalimantan Barat, Tesis, 2004, Sekolah Pascasarjana, Institut Pertanian Bogor, Indonesia, chapter III, p. 32

[12] A. Porte, P. Trichet, D. Bert, and D. Loustau, "Allometric relationship for branch and tree woody biomass of maritime pine (PinuspinasterAit)," Forest Ecology and Management, vol. 158, pp. 71-83, 2002.

[13] J. K. Templeton, "Growth studies in heveabrasiliensis. I. Growth analysis up to seven years after budgrafting," Rubb. Res. Inst. Malaya, 1968, vol. 20, pp. 136-146.

[14] M. Suarti, "Identifikasikanluasanhutan mangrove di Indonesia," Final Report, 2011, Jakarta, pp. 21-35.

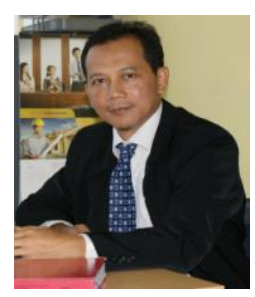

Ari Sandhyavitri graduated from the Civil and Structural Engineering University of Manchester Institute of Science and Technology (UMIST), 2002. He worked as a lecturer at the Civil Engineering Department, Engineering Faculty, Universitas Riau, Pekanbaru, Indonesia. His research interests are decision support systems, water supply infrastructure, mitigating of natural disaster, and wetland environments.

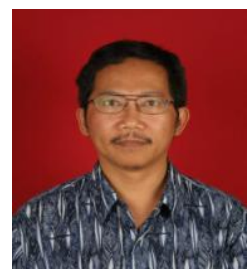

Fajar Restuhadi graduated from the bioinformatics and biotechnology, Dept. Biomolecular Sciences, the Victoria University of Manchester, United Kingdom in 2005. His research interests are in biotechnology and agic, engineering. 


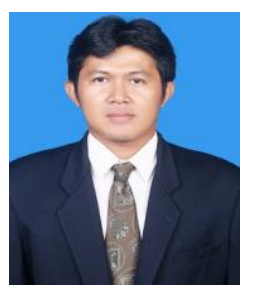

Rudianda Sulaeman graduated from Institut Pertanian Bogor, Indonesia. His research services are for Acquiring Carbon Credits from REDD+, Faculty of Agriculture, Universitas Riau, Pekanbaru, Indonesia.

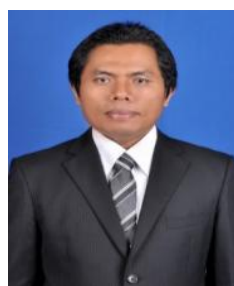

Sigit Sutikno graduated from University of Miyazaki, Japan. His research interests are development of simulation model for evaluating tsunami evacuation and its application. $\mathrm{He}$ is a lecturer at the Civil Engineering Department.

Engineering Faculty, Universitas Riau, Pekanbaru, Indonesia.

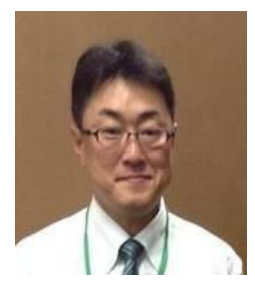

Koichi Yamamoto graduate from School of Engineering, Hokkaido University from 2002 to 2005. He worked as an associate professor, Yamaguchi University. He was a researcher of the River Division, National Institute for Land and Infrastructure Management. 